\title{
Pengaruh Gaya Kepemimpinan, Motivasi, dan Disiplin Kerja Terhadap Kinerja Karyawan Pada PT. Bank Mandiri (Persero) Tbk Cabang Daya Makassar
}

\author{
Multazam$^{1}$, Jeni Kamase² \& Hasbi ${ }^{3}$ \\ 12,3, Magister Manajemen, Universitas Muslim Indonesia. \\ ${ }^{1}$ Koresponden Penulis, E-mail:multazamunir@gmail.com
}

\begin{abstract}
ABSTRAK
Penelitian ini bertujuan untuk mengetahui pengaruh gaya kepemimpinan, motivasi, dan disiplin kerja terhadap kinerja karyawan pada PT. Bank Mandiri Cabang Daya Makassar. Jenis penelitian ini, yaitu penelitian asosiatif. Ada beberapa variabel yang dihubungkan dalam penelitian ini adalah variabel Gaya Kepemimpinan $\left(X_{1}\right)$, Motivasi $\left(X_{2}\right)$, Disiplin Kerja $\left(X_{3}\right)$, dan Kinerja Karyawan $(Y)$. Jenis data yang digunakan adalah data primer dan data sekunder. Data primer merupakan data yang diperoleh langsung dari responden dan data sekunder merupakan data yang diperoleh dari dokumen yang didapat dari PT. Bank Mandiri Cabang Daya Makassar untuk mendukung penelitian. Teknik analisis penelitian ini menggunakan teknik analisis deskriptif dan regresi linier berganda dengan populasi dan sampel yang berjumlah sama, yaitu 31 orang. Hasil penelitian ini diperoleh bahwa gaya kepemimpinan berpengaruh terhadap kinerja karyawan, motivasi berpengaruh terhadap kinerja karyawan dan disiplin kerja berpengaruh terhadap kinerja karyawan Pada PT. Bank Mandiri (Persero) Tbk, Cabang Daya Makassar.
\end{abstract}

Kata Kunci: Gaya Kepemimpinan; Motivasi; Disiplin Kerja; Kinerja Karyawan

\begin{abstract}
This study aims to determine the effect of leadership style, motivation, and work discipline on employee performance at PT. Bank Mandiri Branch Daya Makassar. This type of research, namely associative research. There are several variables that are linked in this study, namely the variable Leadership Style (X1), Motivation (X2), Work Discipline (X3), and Employee Performance (Y). The types of data used are primary data and secondary data. Primary data is data obtained directly from respondents and secondary data is data obtained from documents obtained from PT. Bank Mandiri Daya Makassar Branch to support research. The analysis technique of this research uses descriptive analysis techniques and multiple linear regression with the same population and sample, namely 31 people. The results of this study indicate that leadership style affects employee performance, motivation affects employee performance and work discipline affects employee performance at PT. Bank Mandiri (Persero) Tbk, Daya Makassar Branch.
\end{abstract}

Keywords: Leadership Style, Motivation, Work Discipline, Employee Performance 


\section{PENDAHULUAN}

Dalam rangka mencapai tujuannya, setiap organisasi manajemen yang berkaitan dengan Upaya-upaya untuk meningkatkan efektifitas organisasi (Yudhadiningsih, 2011). Dalam penyelenggaraan negara untuk mewujudkan pemerintah yang baik (good gavernance) yaitu pemerintahan yang bersih, transparan, akuntabel, partisifatif dan mampu menjawab perubahan secara efektif (Sulistiawan, Ispriyarso \& Ristyawati, 2019). Pemerintah sebagai sebuah organisasi dalam menampilkan kinerja pelayanan publik yang tinggi tentu saja harus didukung oleh sumber daya yang ada. Salah satu sumber daya yang penting dalam organisasi yang sangat berarti dalam menopang keberhasilan mencapai tujuan adalah sumber daya manusia (Hariandja, 2002).

Fenomena yang terjadi pada PT. Bank Mandiri Cabang Daya Makassar adalah kurangnya kesadaran diri, prestasi kerja, tanggung jawab, serta pengawasan dan pembinaan. Hal ini menjadi tanggung jawab pemimpin. Dengan berbagai dinamika yang terjadi, secara kontektual harapan sebagai mana yang di jelaskan belum terwujud sehingga optimalisasi kinerja karyawan pada PT. Bank Mandiri Cabang Daya Makassar masih belum menunjukan hasil yang optimal.

Tantangan dalam mengembangkan strategi organisasi yang jelas terletak pada organisasi di satu sisi dan tergantung pada kepemimpinan (Porter, 1996) Sedang agar memiliki keefektifan Green Berg dan (Barson, et,al 2000) menyatakan bahwa Kepemimpinan merupakan suatu unsur kunci dalam keefektifan organisasi.

Seiring dengan perubahan lingkungan organisasi yang semakin kompleks dan kompetitif, menuntut kesiapan pemimpin agar perusahaan tetap bertahan. Model kepemimpinan mutakhir seperti kepemimpinan transformasi organisasi, akan memainkan peranan yang penting bagi setiap organisasi (Anatan, 2005).

Kepemimpinan transformasional meliputi pengembangan hubugan yang lebih dekat antara pemimpin dengan pengikutnya, bukan hanya sekedar sebuah perjanjian tetapi lebih berdasarkan kepada kepercayaan dan komitmen (Jung dan Avolio, 1999). (Bass dan Bruce, 2003) mendefenisikan bahwa kepemimpinan transformasional sebagai pemimpin yang mempunyai kekuatan untuk mempengaruhi bawahan dengan cara-cara tertentu. Bawahan merasa percaya, kagum, loyal dan hormat terhadap atasannya sehingga bawahan termotivasi untuk berbuat lebih banyak dari apa yang biasa dilakukan dan diharapkannya (Sunardiansyah, 2016). Kepemimpinan transformasional pada prinsipnya memotivasi bawahan untuk berbuat lebih baik dari apa yang bisa dilakukan, dengan kata lain dapat meningkatkan kepercayaan atau keyakinan dari bawahan yang akan berpengaruh terhadap peningkatan kerja (Jufrizen, 2017).

Seorang pemimpin dapat mentransformasikan bawahannya melalui empat komponen, yang terdiri dari (Umam, 2019): (1) Pengaruh Idealisme. Pemimpin yang memiliki karisma menunjukan pendirian, menekankan kepercayaan, menempatkan diri pada isu-isu yang sulit, menunjukan nilai yang paling penting, menekankan pentingnya tujuan, komitmen dan konsekuen etika dari keputusan, serta memiliki Visi dan sence of mission; (2) Motivasi Inspirasion. Pemimpin mempunyai visi yang menarik untuk masa depan, menetapkan standar yang tinggi bagi para bawahan, optimis dan antusiasme, memberikan dorongan dar arti terhadap apa yang perlu 
dilakukan. Sehingga pemimpin semacam ini akan memperbesar optimisme dan antusiasme bawahan serta motivasi dan menginspirasi bawahannya untuk melebihi harapan motivasional awal melalui dukungan emosional dan daya tarik emosional. (3) Stimulasi Intelektual. Pemimpin yang mendorong bawahan untuk lebih kreatif, menghilangkan keengganan bawahan untuk mengeluarkan ide-idenya dan dapat menyelesaikan permasalahan yang ada mengunakan intelegensi dan alasan-alasan yang rasional dari pada hanya didasarkan pada opini-opini atau perkiraan-perkiraan semata. (4) Konsiderasi individual. Pemimpin mampu memperlakukan orang yang sebagai individu, mempertimbangkan kebutuhan individual dan aspirasi-aspirasi, mendengarkan, mendidik dan melatih bawahan, sehingga pemimpin seperti ini memberikan perhatian personal terhadap bawahannya yang melihat bawahannya sebagai individual dan menawarkan perhatian khusus untuk mengembangkan bawahan demi kinerja yang bagus . untuk menunjang keberhasilan manajemen dibutuhkan seorang pemimpin yang dapat melaksanakan tugas dan fungsi manajemen.

Disisi lain pemimpin memberikan imbalan atau penghargaan tertentu (misalnya, bonus) kepada bawahan jika bawahan mampu memenuhi harapan pemimpin (misalnya, kinerja karyawan tinggi). bawahan berupaya memenuhi harapan pemimpin disamping untuk memperoleh imbalan atau penghargaan, juga untuk menghidarkan diri dari sanksi atau hukuman.

PT. Bank Mandiri didirikan pada 2 Oktober 1998, sebagai bagian dari program restrukturisasi perbankan yang dilaksanakan oleh pemerintah Indonesia. Pada bulan Juli 1999, empat bank pemerintah, yaitu Bank Bumi Daya, Bank Dagang Negara, Bank Ekspor Impor Indonesia dan Bank Pembangunan Indonesia dilebur menjadi Bank Mandiri, dimana masing-masing bank tersebut memiliki peran yang tak terpisahkan dalam pembangunan perekonomian Indonesia. Sampai dengan hari ini, Bank Mandiri meneruskan tradisi selama lebih dari 140 tahun memberikan kontribusi dalam dunia perbankan dan perekonomian Indonesia.

Berdasarkan hasil pra survey yang dilakukan oleh peneliti melalui wawancara kepada beberapa orang karyawan PT. Bank Mandiri (Persero) Tbk Makassar Cabang Daya bahwa gaya kepemimpinan yang ada di PT. Bank Mandiri Cabang Daya Makassar adalah gaya kepemimpinan Transformasional Kepemimpinan transformasional sebagai pemimpin yang mempunyai kekuatan untuk mempengaruhi bawahan dengan cara-cara tertentu. Dengan penerapan kepemimpinan transformasional bawahan akan merasa dipercaya, dihargai, loyal dan respek kepada pimpinannya. Pada akhirnya bawahan akan termotivasi untuk melakukan lebih dari yang diharapkan. Namun belum terlaksana dengan baik.

Selain itu peneliti juga melakukan wawancara kepada Kepala Cabang PT. Bank Mandiri Cabang Daya Makassar mengenai disiplin kerja . Berdasarkan informasi, sebelum kantor buka pukul 08.00 WIB karyawan sudah harus hadir di kantor paling lambat pukul 06.45 WIB karena akan diadakannya briefing oleh Kepala Cabang pada pukul 07.00 WIB. Tetapi berdasarkan wawancara penulis kepada karyawan, masih ada karyawan yang datang diatas pukul 07.00 WIB . ini menunjukkan kurangnya disiplin. 
Gambar 3.1

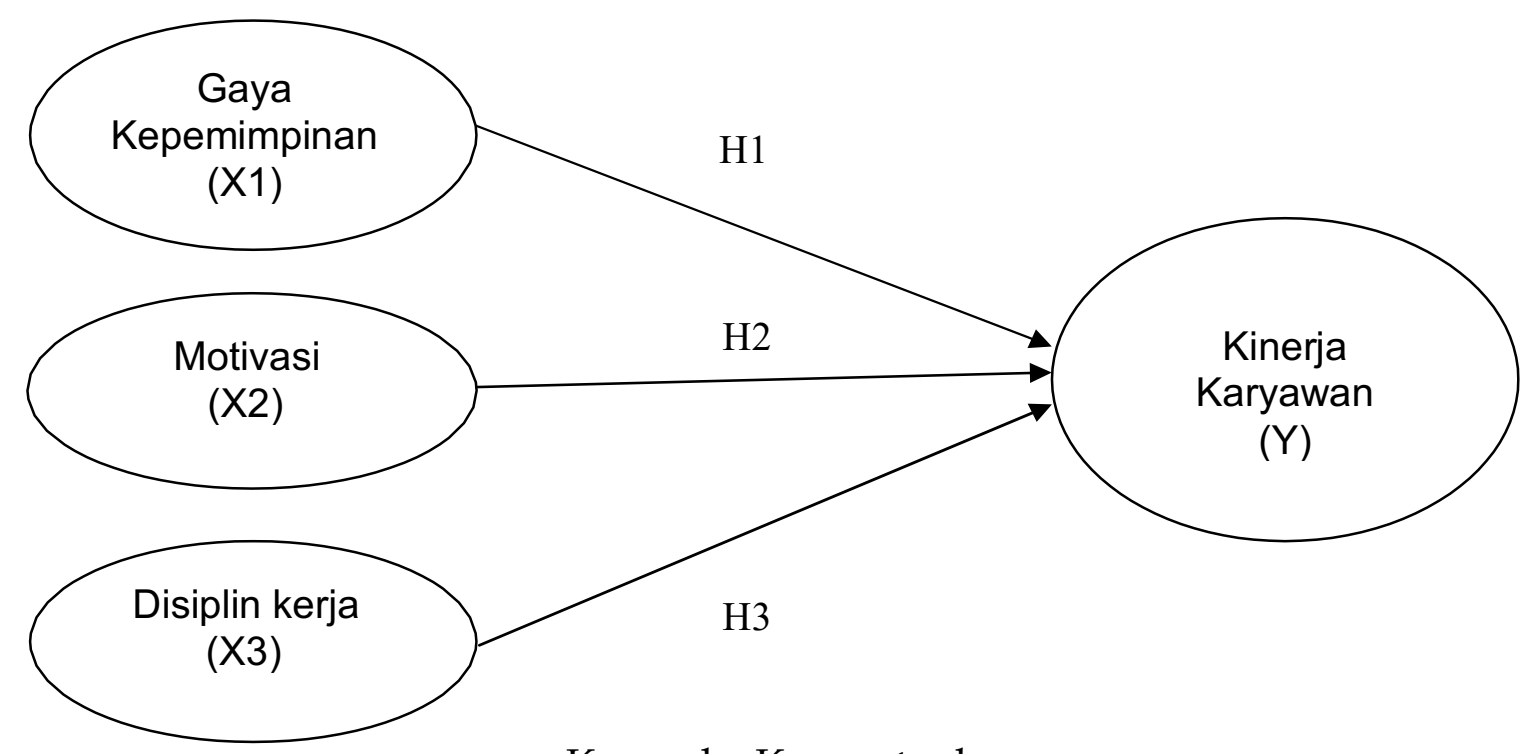

Kerangka Konseptual

Sumber: konsep yang dikembangkan dalam penelitian ini.

\section{Hipotesis}

Berdasarkan kerangka pemikiran diatas maka dapat dikemukakan hipotesis sebagai berikut:

H1: Gaya kepemimpinan berpengaruh positif dan signifikan terhadap kinerja karyawan PT Bank Mandiri (Persero) Tbk, Makassar Cabang Daya.

H2: Motivasi berpengaruh positif dan signifikan terhadap kinerja karyawan PT Bank Mandiri (Persero) Tbk, Makassar Cabang Daya.

H3 : Disiplin Kerja berpengaruh positif dan signifikan terhadap kinerja karyawan PT Bank Mandiri (Persero) Tbk, Makassar Cabang Daya

H4: Gaya Kepemimpinan, Motivasi, dan Disiplin Kerja berpengaruh positif dan signifikan terhadap kinerja karyawan PT Bank Mandiri (Persero) Tbk, Makassar Cabang Daya

\section{METODE PENELITIAN}

Pendekatan penelitian ini adalah penelitian asosiatif. Penelitian asosiatif merupakan penelitian yang bertujuan untuk mengetahui hubungan antara dua variabel atau lebih. Adapun variabel-variabel yang dihubungkan dalam penelitian ini adalah Gaya Kepemimpinan $\left(X_{1}\right)$, Motivasi $\left(X_{2}\right)$, Disiplin Kerja $\left(X_{3}\right)$ dan Kinerja karyawan $(Y)$

Penilitian akan dilaksanakan di PT. Bank Mandiri (Persero) Tbk, Cabang Daya Makassar, yang beralamat di jl. Bukit Khatulistiwa Blok B/9 Paccerakkang kota Makassar, Sulawesi Selatan, 90241. dengan waktu yang dibutuhkan dalam pelaksanaan penilitian direncanakan selama dua bulan dari bulan Juli sampai dengan Agustus 2020.

Pengujian Hipotesis 
Uji Signifikansi Simultan ( Uji Statistik F )

Dalam penelitian ini, uji $\mathrm{F}$ digunakan untuk mengetahui tingkat siginifikansi pengaruh variabel-variabel independen secara bersama-sama (simultan) terhadap variabel dependen (Ghozali, 2005). Dalam penelitian ini, hipotesis yang digunakan adalah:

Ho : Variabel-variabel bebas yaitu gaya kepemimpinan, motivasi dan disiplin tidak mempunyai pengaruh yang signifikan secara bersama-sama terhadap variabel terikatnya yaitu kinerja karyawan.

Ha: Variabel-variabel bebas yaitu gaya kepemimpinan, motivasi dan disiplin mempunyai pengaruh yang signifikan secara bersama-sama terhadap variabel terikatnya yaitu kinerja pegawai.

Dasar pengambilan keputusannya (Ghozali, 2005) adalah dengan menggunakan angka probabilitas signifikansi, yaitu:

a) Apabila probabilitas signifikansi $>0.05$, maka Ho diterima dan Ha ditolak.

b) Apabila probabilitas signifikansi $<0.05$, maka Ho ditolak dan Ha diterima.

\section{HASIL PENELITIAN DAN PEMBAHASAN}

\section{Hasil}

\section{a. Uji Validitas}

Uji validitas digunakan untuk mengukur sah atau tidaknya suatu kuesioner. Suatu kuesioner dikatakan valid jika pernyataan pada kuesioner mampu untuk mengungkapkan sesuatu yang akan diukur oleh kuesioner tersebut. Uji validitas dihitung dengan membandingkan nilai $\mathrm{r}$ hitung (correlated item-total correlations) dengan nilai $r$ tabel jika $r$ hitung $>$ dari $r$ tabel (pada taraf signifikan 5\%) maka pernyataan tersebut dinyatakan valid.

Tabel 1

Uji Validitas

\begin{tabular}{|c|c|c|c|c|}
\hline \multirow{3}{*}{ Variabel } & Item & $\begin{array}{c}\text { Corrected } \\
\text { Item } \\
\text { (R hitung })\end{array}$ & R tabel & Keterangan \\
\hline \multirow{4}{*}{$\begin{array}{c}\text { Gaya Kepemimpinan } \\
(\mathrm{X} 1)\end{array}$} & $\mathrm{X} 1.1$ & .787 & 0.30 & VALID \\
\cline { 2 - 5 } & $\mathrm{X} 1.2$ & .781 & 0.30 & VALID \\
\cline { 2 - 5 } & $\mathrm{X} 1.3$ & .779 & 0.30 & VALID \\
\cline { 2 - 5 } & $\mathrm{X} 1.4$ & .549 & 0.30 & VALID \\
\cline { 2 - 5 } & $\mathrm{X} 1.5$ & .489 & 0.30 & VALID \\
\hline \multirow{3}{*}{ Motivasi $(\mathrm{X} 2)$} & $\mathrm{X} 2.1$ & .822 & 0.30 & VALID \\
\cline { 2 - 5 } & $\mathrm{X} 2.2$ & .856 & 0.30 & VALID \\
\cline { 2 - 5 } & $\mathrm{X} 2.3$ & .834 & 0.30 & VALID \\
\cline { 2 - 5 } & $\mathrm{X} 2.4$ & .866 & 0.30 & VALID \\
\cline { 2 - 5 } & $\mathrm{X} 2.5$ & .839 & 0.30 & VALID \\
\cline { 2 - 5 } & $\mathrm{X} 2.6$ & .801 & 0.30 & VALID \\
\cline { 2 - 5 } & $\mathrm{X} 3.1$ & .787 & 0.30 & VALID \\
\cline { 2 - 5 } & $\mathrm{X} 3.2$ & .793 & 0.30 & VALID \\
\cline { 2 - 5 } Disiplin Kerja (X3) & $\mathrm{X} 3.3$ & .884 & 0.30 & VALID \\
\hline
\end{tabular}




\begin{tabular}{|c|c|c|c|c|}
\hline \multirow{5}{*}{} & $\mathrm{X} 3.4$ & .884 & 0.30 & VALID \\
\cline { 2 - 5 } & $\mathrm{X} 3.5$ & .812 & 0.30 & VALID \\
\cline { 2 - 5 } & $\mathrm{X} 3.6$ & .762 & 0.30 & VALID \\
\hline \multirow{5}{*}{ Kinerja Karyawan $(\mathrm{Y})$} & $\mathrm{Y} 1$ & .822 & 0.30 & VALID \\
\cline { 2 - 5 } & $\mathrm{Y} 2$ & .738 & 0.30 & VALID \\
\cline { 2 - 5 } & $\mathrm{Y} 3$ & .763 & 0.30 & VALID \\
\cline { 2 - 5 } & $\mathrm{Y} 4$ & .887 & 0.30 & VALID \\
\cline { 2 - 5 } & $\mathrm{Y} 5$ & .831 & 0.30 & VALID \\
\cline { 2 - 5 } & $\mathrm{Y} 6$ & .852 & 0.30 & VALID \\
\cline { 2 - 5 } & $\mathrm{Y} 7$ & .887 & 0.30 & VALID \\
\cline { 2 - 5 } & $\mathrm{Y} 8$ & .831 & 0.30 & VALID \\
\cline { 2 - 5 } & $\mathrm{Y} 9$ & .852 & 0.30 & VALID \\
\cline { 2 - 5 } & $\mathrm{Y} 10$ & .852 & 0.30 & VALID \\
\hline
\end{tabular}

Sumber: Data primer, 2020

Dari tabel uji validitas dibawah ini menunjukkan bahwa nilai dari $\mathrm{r}$ hitung lebih besar dibandingkan dengan nilai $r$ tabel $(n-k)$ yang mana $(31-3=28)$ pada $r$ tabel dipeoleh nilai $r$ tabel sebesar 0,30 berarti untuk uji kualitas data yang ditunjukkan dari uji validitas bahwa semua variabel adalah valid.

\section{b. Uji Reliabilitas}

Uji reliabilitas dilakukan dengan melihat hasil perhitungan nilai CronbachAlpha (a). Suatu variabel dikatakan reliabel jika memberikan nilai Cronbach Alpha $(\alpha)>0,60$ yaitu bila penelitian ulang dengan waktu dan variabel yang berbeda akan menghasilkan kesimpulan yang sama. Tetapi sebaliknya bila alpha $<0,6$ maka dianggap kurang handal, artinya bila variabel-variabel tersebut dilakukan penelitian ulang dengan waktu dan variabel yang berbeda akan menghasilkan kesimpulan yang berbeda.

\section{Tabel 2}

Uji Reliabilitas

\begin{tabular}{lcccc}
\multicolumn{1}{c}{ Variabel } & Item & $\begin{array}{c}\text { Cronbach } \\
\text { Alpha }\end{array}$ & $\begin{array}{c}\text { Standar } \\
\text { Reliabilitas }\end{array}$ & Keterangan \\
\hline $\begin{array}{l}\text { Gaya } \\
\text { Kepemimpinan }\end{array}$ & $\mathrm{X} 1$ & .855 & 0.60 & Reliabel \\
\hline Motivasi & $\mathrm{X} 2$ & .946 & 0.60 & Reliabel \\
\hline Disiplin Kerja & $\mathrm{X} 3$ & .940 & 0.60 & Reliabel \\
\hline Kinerja Karyawan & $\mathrm{Y}$ & .962 & 0.60 & Reliabel \\
\hline
\end{tabular}

Sumber : Data primer, 2020

Nilai cronbach's alpha semua variabel memiliki cronbach's alpha lebih besar dari 0,60, sehingga dapat disimpulkan bahwa indikator atau kuesioner yang digunakan untuk semua variabel semuanya dinyatakan handal atau dapat dipercaya sebagai alat ukur. 


\section{Uji Asumsi Klasik}

\section{Uji Normalitas}

Menurut Ghozali (2006) bahwa langkah awal yang harus dilakukan oleh setiap analisis multivariat, khususnya jika tujuannya adalah inferensi jika terdapat normalitas maka residual akan terdistribusi secara normal dan independen. Oleh karena itulah salah satu cara yang dilakukan dalam mendeteksi data yang normal adalah dengan kolmogorov-smirnov. Lebih lanjut menurut Ghozali bahwa nilai asymp sig (2 - tailed) yang lebih besar dari 0,05 berarti data memiliki distribusi yang normal.

Dalam kaitannya dengan uraian tersebut di atas, akan disajikan hasil olahan data uji normalitas dengan kolmogorov-smirnov yang dapat disajikan pada tabel berikut ini .

\section{Tabel 3}

Uji Normalitas

\begin{tabular}{lcr}
\hline & & $\begin{array}{c}\text { Unstandardized } \\
\text { Residual }\end{array}$ \\
\hline $\mathrm{N}$ & Mean & 31 \\
Normal Parameters & Std. Deviation & .0000000 \\
& Absolute & .27153408 \\
Most Extreme & Positive & .096 \\
Differences & Negative & .096 \\
& & -.085 \\
Test Statistic & & .096 \\
Asymp. Sig (2-tailed) & & $.200 \mathrm{c,d}$ \\
\hline Sumber: Data primer, 2020 &
\end{tabular}

Berdasarkan tabel 15 yakni hasil uji normalitas dengan nilai sig $=0,200>0,05$ berarti dapatlah disimpulkan bahwa data yang akan digunakan dalam pengujian regresi memiliki distribusi yang normal, alasannya karena memiliki nilai sig > 0,05.

\section{Uji Multikolinieritas}

Uji multikolineritas dilakukan untuk mengetahui adanya keterikatan antara variabel independen, dengan kata lain bahwa setiap variabel dependen dapat dijelaskan oleh variabel independent lainnya, sehingga untuk mengetahui apakah ada kolinearitas dalam penelitian ini maka dapat dilihat dari nilai variance inflation factor (VIF).

Batas nilai VIF yang lebih dari 10 menunjukkan adanya kolinearitas yang tinggi, apabila terjadi gejala multikolinearitas, salah satu langkah untuk memperbaiki model adalah dengan menghilangkan variabel dalam model regresi. Untuk lebih jelasnya hasil uji multikolineritas melalui tabel berikut ini: 
Tabel 4

Uji Multikolinieritas

\begin{tabular}{lcccc}
\hline \multirow{2}{*}{ Variabel } & \multicolumn{2}{c}{$\begin{array}{c}\text { Colineritas } \\
\text { Statistik }\end{array}$} & VIF & \\
\cline { 2 - 4 } & $\begin{array}{c}\text { Toleranc } \\
\text { e }\end{array}$ & VIF & Standar & Keputusan \\
\hline GAYA KEPEMIMPINAN & .908 & 1.102 & & $\begin{array}{c}\text { Tidak ada } \\
\text { gejala } \\
\text { multikolinerita } \\
\text { s }\end{array}$ \\
\hline MOTIVASI & & & 10 & $\begin{array}{c}\text { Tidak ada } \\
\text { gejala }\end{array}$ \\
& .324 & 3.082 & & $\begin{array}{c}\text { multikolinerita } \\
\text { s }\end{array}$ \\
\hline DISIPLIN KERJA & & & 10 & $\begin{array}{c}\text { Tidak ada } \\
\text { gejala } \\
\text { multikolinerita } \\
\text { s }\end{array}$ \\
\hline
\end{tabular}

Sumber : Data primer, 2020

\section{Uji Heterokedastisitas}

Heterokesdastisitas akan mengakibatkan penaksiran koefisien-koefisien regresi menjadi tidak efisien. Diagnosis adanya heterokesdastisitas dapat dilakukan dengan memperhatikan residual dan variabel yang diprediksi. Jika sebaran titik dalam plot terpencar disekitar angka nol (0 pada sumbu Y) dan tidak membentuk pola atau trend garis tertentu, maka dapat dikatakan bahwa model tidak memenuhi asumsi heterokesdastisitas atau model regresi dikatakan memenuhi syarat untuk memprediksi. Heterokesdastisitas diuji dengan menggunakan grafik scatterplot. Adapun dasar pengambilan keputusan tersebut adalah:

- Jika ada pola tertentu yang membentuk pola tertentu yang teratur, maka terjadi heterokesdastisitas

- Jika tidak ada pola yang jelas serta titik-titik menyebar maka tidak terjadi heterokesdastisitas. 
Hasil uji heterokesdastisitas ditunjukkan pada gambar dibawah ini :

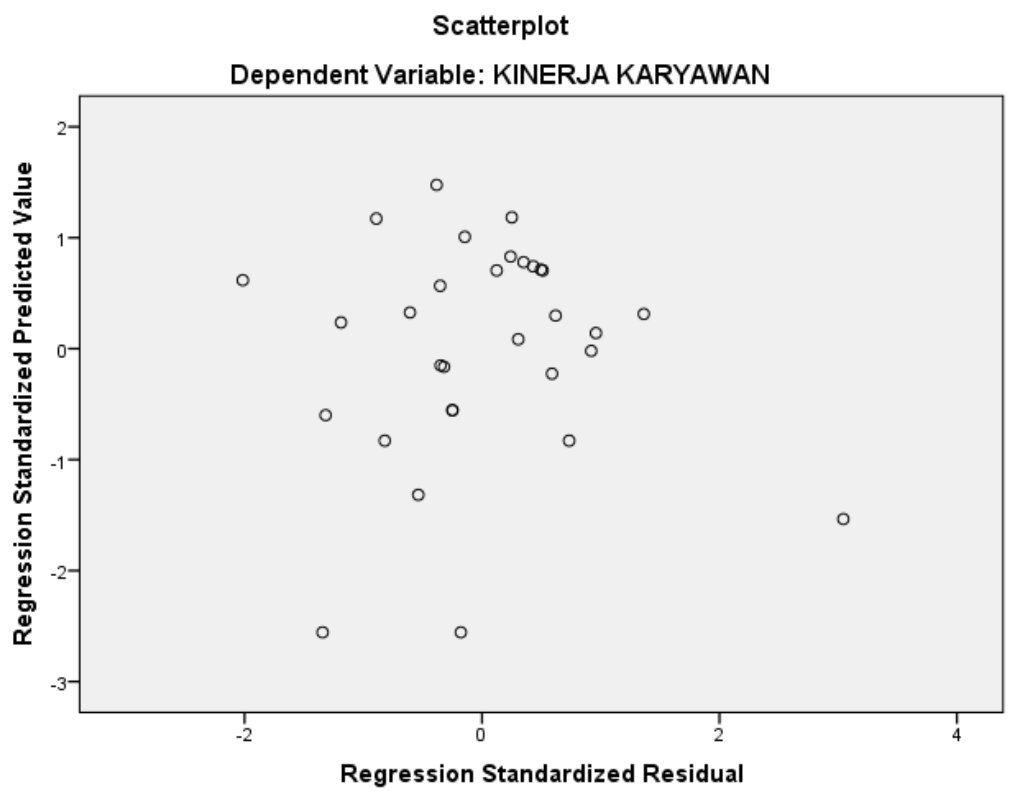

Berdasarkan grafik/gambar terlihat tidak ada pola yang jelas serta titik menyebar di atas dan dibawah dari angka 0 , sehingga dapat disimpulkan bahwa tidak terjadi heterokedastisitas.

\section{Analisis Data Penelitian}

Analisis data dilakukan dengan menggunakan regresi linear berganda dengan tujuan untuk mengetahui pengaruh gaya kepemimpinan, motivasi dan disiplin kerja terhadap kinerja karyawan. Statistical Package For Social Science (SPSS) akan digunakan untuk membantu proses analisis linear berganda.

\section{Tabel 5}

Hasil Regresi Berganda

\begin{tabular}{|c|c|c|c|c|c|}
\hline & & $\begin{array}{l}\text { Unstadardized } \\
\text { Coefficients }\end{array}$ & $\begin{array}{l}\text { Standardized } \\
\text { Coefficients }\end{array}$ & & \\
\hline & B & Std. Error & Beta & $\mathbf{T}$ & Sig \\
\hline (Constant) & .943 & .404 & & 2.333 & .027 \\
\hline $\begin{array}{l}\text { Gaya } \\
\text { Kepemimpinan }\end{array}$ & .157 & .076 & .167 & 2.060 & .049 \\
\hline Motivasi & .327 & .123 & .361 & 2.668 & .013 \\
\hline Disiplin & .627 & .133 & .621 & 4.722 & .000 \\
\hline
\end{tabular}

Sumber : Data primer, 2020

Berdasarkan pada tabel diatas maka didapatkan persamaan regresi linier berganda sebagai berikut:

$$
\mathrm{Y}=0,943+0,157 \mathrm{X} 1+0,327 \mathrm{X} 2+0,627 \mathrm{X} 3
$$


Persamaan di atas dapat dijelaskan sebagai berikut:

a. Nilai konstanta sebesar 0,943 menunjukkan bahwa bila variabel independennya nol maka kinerja pegawai yang dihasilkan sebesar 0,943.

b. Nilai 0,157 pada variabel gaya kepemimpinan (X1) adalah bernilai positif sehingga dapat dikatakan bahwa semakin tinggi gaya kepemimpinan, berarti akan semakin tinggi pula kinerja pegawai. Koefisien regresi 0,157 menyatakan bahwa setiap penambahan 1 gaya kepemimpinan maka akan meningkatkan kinerja pegawai sebesar 0,157 satuan. Sehingga gaya kepemimpinan berhubungan positif terhadap kinerja pegawai, dengan asumsi variabel independen lain dianggap konstan.

c. Nilai 0,327 pada variabel motivasi (X2) adalah bernilai positif sehingga dapat dikatakan bahwa semakin tinggi motivasi, berarti akan semakin tinggi pula kinerja pegawai. Koefisien regresi 0,327 menyatakan bahwa setiap penambahan 1 motivasi maka akan meningkatkan kinerja pegawai sebesar 0,327 satuan. Sehingga motivasi berhubungan positif terhadap kinerja pegawai, dengan asumsi variabel independen lain dianggap konstan.

d. Nilai 0,627 pada variabel disiplin kerja (X3) adalah bernilai positif sehingga dapat dikatakan bahwa semakin tinggi sikap kerja, berarti akan semakin tinggi pula kinerja pegawai. Koefisien regresi 0,465 menyatakan bahwa setiap penambahan 1 disiplin kerja maka akan meningkatkan kinerja pegawai sebesar 0,627 satuan. Sehingga disiplin kerja berhubungan positif terhadap kinerja pegawai, dengan asumsi variabel independen lain dianggap konstan.

\section{a. Uji F (Simultan)}

Uji F digunakan untuk menguji apakah variabel independen secara serempak berpengaruh signifikan terhadap variabel dependen. Dimana F hitung $>$ F tabel, maka hipotesis diterima atau secara bersama-sama variabel bebas dapat menerangkan variabel terikatnya secara serentak. Sebaliknya apabila F hitung $<$ F tabel, maka HO diterima atau secara bersama-sama variabel bebas tidak memiliki pengaruh terhadap variabel terikat.

Untuk mengetahui signifikan atau tidak pengaruh secara bersama-sama variabel bebas terhadap variabel terikat maka digunakan probability sebesar $5 \%(\alpha=0,05)$.

\section{Tabel 6}

\section{Uji F (Simultan)}

\begin{tabular}{cccccc} 
Model & $\begin{array}{c}\text { Sum of } \\
\text { Squares }\end{array}$ & Df & $\begin{array}{c}\text { Mean } \\
\text { Square }\end{array}$ & F & Sig. \\
\hline Regression & 11.565 & 3 & 3.855 & 47.057 & $.000^{\mathrm{b}}$ \\
\hline Residual & 2.212 & 27 & .082 & & \\
\hline Total & 13.777 & 30 & & & \\
Sumber : Data primer, 2020 & & &
\end{tabular}

Dengan tingkat signifikan 5\% dan derajat kebebasan df1 = 3 dan df $2=27$ maka $\mathrm{f}$ tabel didapat (3:27) $=2,96$. Berdasarkan uji anova atau uji $\mathrm{F}$ dari output SPSS, terlihat bahwa diperoleh $\mathrm{f}$ hitung sebesar 47,057 > 2,96 nilai $\mathrm{f}$ tabel dan probabilitas sebesar $0,000<0,05$. Secara lebih tepat, nilai $\mathrm{F}$ hitung dibandingkan dengan $\mathrm{F}$ tabel dimana 
jika $\mathrm{F}$ hitung $>\mathrm{F}$ tabel maka secara simultan variabel-variabel independen berpengaruh positif dan signifikan terhadap variabel dependen.

\section{b. Uji T (Parsial)}

Uji $t$ digunakan untuk mengetahui pengaruh masing-masing indikator dari variabel bebas terhadap variabel terikat. Uji $t$ dilakukan dengan membandingkan antara $t-$ hitung dengan t-tabel. Untuk menentukan nilai t-tabel, maka ditentukan dengan tingkat signifikan $5 \%$ dengan derajat kebebasan $\mathrm{df}=(\mathrm{n}-\mathrm{k}-1)$ dimana $\mathrm{n}$ adalah jumlah responden dan $\mathrm{k}$ adalah jumlah indikator/variabel.

\section{Tabel 7}

Uji T (Parsial)

\begin{tabular}{lcccc|c} 
& \multicolumn{3}{c}{$\begin{array}{c}\text { Unstadardized } \\
\text { Coefficients }\end{array}$} & $\begin{array}{c}\text { Standardized } \\
\text { Coefficients }\end{array}$ & \\
\hline & B & Std. Error & Beta & t & Sig \\
\hline (Constant) & .943 & .404 & & 2.333 & .027 \\
\hline $\begin{array}{l}\text { Gaya } \\
\text { Kepemimpinan }\end{array}$ & .157 & .076 & .167 & 2.060 & .049 \\
\hline Motivasi & .327 & .123 & .361 & 2.668 & .013 \\
\hline Disiplin & .627 & .133 & .621 & 4.722 & .000 \\
\hline
\end{tabular}

Sumber : Data primer, 2020

Berdasarkan tabel diatas untuk t hitung gaya kepemimpinan sebesar 2,060 dan untuk nilai $\mathrm{t}$ tabel dari hasil $\mathrm{n}-\mathrm{k}-1$ ( $\mathrm{n}=$ responden, $\mathrm{k}=$ variabel independen) sebesar 1,705. Dengan begitu berdasarkan nilai t hitung sebesar 2,060 > 1,705 dan untuk nilai probabilitas sebesar 0,04 $<0,05$ maka dapat disimpulkan $\mathrm{H} 0$ ditolak dan Ha diterima, dengan demikian gaya kepemimpinan berpengaruh signifikan secara parsial terhadap kinerja pegawai.

Untuk $\mathrm{t}$ hitung keterampilan sebesar 2,668 dan untuk nilai $\mathrm{t}$ tabel dari hasil $\mathrm{n}-\mathrm{k}-1$ ( $\mathrm{n}=$ responden, $\mathrm{k}=$ variabel independen) sebesar 1,705. Dengan begitu berdasarkan nilai t hitung sebesar 2,668 > 1,705 dan untuk nilai probabilitas sebesar 0,01<0,05 maka dapat disimpulkan H0 ditolak dan Ha diterima, dengan demikian motivasi berpengaruh signifikan secara parsial terhadap kinerja pegawai.

Untuk $\mathrm{t}$ hitung disiplin kerja sebesar 4,722 dan untuk nilai $\mathrm{t}$ tabel dari hasil $\mathrm{n}-\mathrm{k}-1$ ( $\mathrm{n}=$ responden, $\mathrm{k}=$ variabel independen) sebesar 1,705. Dengan begitu berdasarkan nilai t hitung sebesar 4,722 > 1,705 dan untuk nilai probabilitas sebesar 0,000<0,00 maka dapat disimpulkan H0 ditolak dan Ha diterima, dengan demikian disiplin kerja berpengaruh signifikan secara parsial terhadap kinerja pegawai.

\section{Koefisien Determinasi}

Koefisien determinasi digunakan dalam mendeteksi seberapa jauh hubungan dan kemampuan model dalam menjelaskan variabel dependen. Pada data yang diolah terdapat empat variabel independen. Seperti pada tabel berikut. 
Tabel 7

Koefisien Determinasi

\begin{tabular}{ccccc} 
Model & $\mathrm{R}$ & R Square & $\begin{array}{c}\text { Adjusted R } \\
\text { Square }\end{array}$ & $\begin{array}{c}\text { Std. Error of } \\
\text { the Estimate }\end{array}$ \\
\hline 1 & $.916^{\mathrm{a}}$ & .839 & .822 & .286 \\
\hline Sumber: Data primer 2020 & & &
\end{tabular}

Pada tabel di atas terlihat bahwa $\mathrm{R}$ memperoleh nilai korelasi sebesar $\mathrm{R}=0,916$ yang artinya korelasi atau hubungan antara gaya kepemimpinan, motivasi, dan disiplin kerja mempunyai pengaruh terhadap kinerja pegawai sebesar 91,6\%. Kemudian nilai koefisien determinasi atau $\mathrm{R}$ Square sebesar =0,839 yang artinya sebesar 83,9\% pengaruh kinerja pegawai dipengaruhi oleh gaya kepemimpinan, motivasi, dan disiplin kerja.

\section{Pembahasan}

\section{Pengaruh Gaya Kepemimpinan terhadap Kinerja Karyawan}

Gaya kepemimpinan merupakan hal yang penting dalam sebuah organisasi dan perusahaan dalam mencapai tujuan yang di inginkan sebuah organisasi maupun perusahaan, gaya kepemimpinan juga mempengaruhi kinerja pegawai pada perusahaan atau organisasi. Gaya kepemimpinan yang baik mampu menghasilkan hasil yang baik bagi perusahaan serta menghadirkan rasa nyaman pada pegawai saat bekerja. Siagian (2010:128) mengemukakan bahwa gaya kepemimpinan yang baik adalah pemimpin yang dapat memberikan pengaruh, informasi, pengambilan keputusan, dan dapat memberkan motivasi yang bertujuan untuk meningkatkan organisasi atau pegawai.

Seorang pemimpin harus dapat menciptakan hubungan kerja yang harmonis, baik antara sesama pegawai, maupun antara atasan dengan bawahan. Kemampuan pemimpin dalam mengarahkan serta mengkoordinasikan potensi yang dimiliki seluruh pegawai akan terkait dengan peningkatan motivasi dalam melakukan pekerjaan. kepemimpinan yang efektif dalam hal motivasi kerja dapat diwujudkan dengan kombinasi perilaku, dimana pemimpin harus bisa mengubah kepemimpinannya sesuai dengan situasi organisasi.

Berdasarkan hasil penelitian ini diperoleh $\mathrm{t} t$ hitung gaya kepemimpinan sebesar 2,060 dan untuk nilai $\mathrm{t}$ tabel dari hasil $\mathrm{n}-\mathrm{k}-1$ ( $\mathrm{n}=$ responden, $\mathrm{k}=$ variabel independen) sebesar 1,705. Dengan begitu berdasarkan nilai t hitung sebesar 2,060 > 1,705 dan untuk nilai probabilitas sebesar 0,04 < 0,05 maka dapat disimpulkan Ho ditolak dan Ha diterima, dengan demikian gaya kepemimpinan berpengaruh signifikan secara parsial terhadap kinerja pegawai.

Tanpa adanya gaya kepemimpinan yang baik maka suatu organisasi atau perusahaan akan sulit mencapai hasil yang optimal. Hal yang sama dinyatakan oleh Wa Syazhash Putra Bahrum (2015) mengatakan dalam penelitianya bahwa hasil uji 
analisis menujukan bahwa gaya kepemimpinan berpengaruh terhadap kinerja pegawai dan lingkungan kerja berpengaruh terhadap kinerja pegawai dalam jurnal Pengaruh Kepemimpinan dan Motivasi terhadap Kinerja Pegawai (Studi Pada Pegawai Lembaga Dewan Kawasan Perdagangan Bebas Pelabuhan Bebas Batam Bintan Karimun) dengan hasil penelitian menunjukkan adanya pengaruh gaya kepemimpian yang signifikan.

\section{Pengaruh Motivasi terhadap Kinerja Karyawan}

Motivasi adalah tindakan memberikan daya perangsang kepada pegawai yang bersangkutan agar pegawai tersebut bekerja dengan segala daya dan upayanya (Wahab, 2012). Motivasi menjadi hal yang sangat penting bagi pekerja sosial, pekerja sosial yang termotivasi akan merasa lebih bahagia, sehat dan ingin datang untuk bekerja. Kurangnya motivasi dapat berdampak serius bagi tingkat absensi dan keterlibatan pekerja sosial. Semangat kerja yang rendah dapat merugikan pencapaian tujuan bisnis. Oleh karena itu, perusahaan harus memperhatikan motivasi agar antara perusahaan dan pegawai dapat berjalan dengan lancar tanpa saling merugikan.

Hasil penelitian ini diperoleh $\mathrm{t}$ hitung keterampilan sebesar 2,668 dan untuk nilai $\mathrm{t}$ tabel dari hasil n-k-1 ( $\mathrm{n}=$ responden, $\mathrm{k}=$ variabel independen) sebesar 1,705. Dengan begitu berdasarkan nilai t hitung sebesar 2,668 > 1,705 dan untuk nilai probabilitas sebesar 0,01 < 0,05 maka dapat disimpulkan H0 ditolak dan Ha diterima, dengan demikian motivasi berpengaruh signifikan secara parsial terhadap kinerja pegawai.

Penelitian ini sejalan dengan penelitian yang telah dilakukan oleh Rachmi Yulianti (2015) yang meneliti masalah pengaruh motivasi terhadap kinerja pegawai melalui variabel kepuasan kerja. Rachmi membuktikan bahwa motivasi berpengaruh secara langsung terhadap kinerja pegawai.

\section{Pengaruh Disiplin Kerja terhadap Kinerja Karyawan}

Disiplin menunjukkan suatu kondisi atau sikap hormat yang ada pada diri karyawan terhadap peraturan dan ketetapan perusahaan. Dengan demikian bila peraturan atau ketetapan yang ada dalam perusahaan diabaikan, atau sering dilanggar, maka karyawan mempunyai disiplin yang buruk. Sebaliknya bila karyawan tunduk pada ketetapan perusahaan, menggambarkan adanya kondisi disiplin yang baik.

Hasil uji hipotesis maka diperoleh $\mathrm{t}$ hitung disiplin kerja sebesar 4,722 dan untuk nilai $\mathrm{t}$ tabel dari hasil $\mathrm{n}-\mathrm{k}-1$ ( $\mathrm{n}=$ responden, $\mathrm{k}=$ variabel independen) sebesar 1,705. Dengan begitu berdasarkan nilai t hitung sebesar 4,722 >1,705 dan untuk nilai probabilitas sebesar 0,000 $<0,00$ maka dapat disimpulkan $\mathrm{H} 0$ ditolak dan Ha diterima, dengan demikian disiplin kerja berpengaruh signifikan secara parsial terhadap kinerja pegawai.

Disiplin perlu untuk mengatur tindakan kelompok, dimana setiap anggotanya harus mengendalikan dorongan hatinya dan bekerja sama demi kebaikan bersama. Dengan kata lain, mereka harus secara sadar tunduk pada aturan perilaku yang diadakan oleh kepemimpinan organisasi, yang ditujukan pada tujuan yang hendak dicapai. Dalam pelaksanaan disiplin kerja, peraturan dan ketetapan perusahaan hendaknya masuk akal dan bersifat adil bagi seluruh karyawan. Selain itu, hendaknya peraturan 
tersebut juga dikomunikasikan sehingga para pegawai tahu apa yang menjadi larangan dan apa yang tidak.

Hasil penelitian ini sejalan dengan penelitian yang dilakukan ole Rika Widyaningtyas (2016) yang meneliti juga masalah pengaruh disiplin kerja terhadap kinerja karyawan. Rika juga memperoleh hasil bahwa disiplin kerja memiliki pengaruh terhadap kinerja karyawan.

\section{KESIMPULAN}

1. Gaya Kepemimpinan berpengaruh positif dan signifikan terhadap kinerja pegawai pada PT Bank Mandiri (Persero) Tbk Cabang Daya Makassar.

2. Motivasi berpengaruh positif dan signifikan terhadap kinerja pegawai pada PT Bank Mandiri (Persero) Tbk Cabang Daya Makassar.

3. Disiplin kerja berpengaruh positif dan signifikan terhadap kinerja pegawai pada PT Bank Mandiri (Persero) Tbk Cabang Daya Makassar.

\section{DAFTAR PUSTAKA}

Anatan, L. (2005). Meraih keunggulan kompetitif berkelanjutan melalui pengintegrasian fungsi sumber daya manusia dalam strategi bisnis. Jurnal Manajemen Maranatha, 4(2), 28-40.

Avolio, B. J., Bass, B. M., \& Jung, D. I. (1999). Re-examining the components of transformational and transactional leadership using the Multifactor Leadership. Journal of occupational and organizational psychology, 72(4), 441-462.

Barson, R. J., Foster, G., Struck, T., Ratchev, S., Pawar, K., Weber, F., \& Wunram, M. (2000, October). Inter-and intra-organisational barriers to sharing knowledge in the extended supply-chain. In Proceedings of the eBusiness and eWork (pp. 18-20).

Bass, B. M., \& Avolio, B. J. (2003). Multifactor leadership questionnaire feedback report. New York: Mind Garden Inc.

Hariandja, M. T. E. (2002). Manajemen sumber daya manusia. Grasindo.

Jufrizen, J. (2017). Efek Moderasi Etika Kerja Pada Pengaruh Kepemimpinan Transformasional dan Budaya Organisasi Terhadap Kinerja Karyawan. E-Mabis: Jurnal Ekonomi Manajemen Dan Bisnis, 18(2), 145-158.

Porter, M. E. (1996). What is strategy?. Harvard business review, 74(6), 61-78.

Sunardiansyah, Y. A. (2016). Kepemimpinan Transformasional Dan Motivasi Kerja Terhadap Kinerja Pegawai Badan Penanaman Modal Dan Promosi Daerah Kabupaten Kutai Kartanegara. Jurnal Analisis Bisnis Ekonomi, 14(2), 162-178.

Sulistiawan, A., Ispriyarso, B., \& Ristyawati, A. (2019). Bentuk Dan Mekanisme Perencanaan Keuangan Daerah Yang Partisipatif Guna Mewujudkan Akuntabilitas Publik. Jurnal Pembangunan Hukum Indonesia, 1(2), 146-157.

Umam, M. K. (2019). Dimensi Kepemimpinan Transformatif Era Disrupsi Perspektif Manajerial Birokrasi. AL-WIJDÃ N: Journal of Islamic Education Studies, 4(2), 127146. 
Yudhaningsih, R. (2011). Peningkatan efektivitas kerja melalui komitmen, perubahan dan budaya organisasi. Jurnal Pengembangan Humaniora, 11(1), 40-50. 